\title{
Assessment of ecosystem services provision: The case of mountain olive groves in Los Pedroches, southern Spain
}

\author{
Jesús Fernández-Habas*, Pedro Sánchez-Zamora**, \\ Felisa Ceña-Delgado**, Rosa Gallardo-Cobos**
}

DOI: $10.30682 / \mathrm{nm} 1802 \mathrm{~d}$

JEL codes: Q57, Q01, Q18

\begin{abstract}
The mountain olive grove is an agroecosystem that, despite low yields and high costs, is recognised for its marked multifunctionality and its significant potential to provide ecosystem services. Due to the close relationship between ecosystem services and human well-being, advancement in the identification and assessment of potential benefits is of great interest. Thus, by using the multi-criteria decision-making technique Analytic Network Process (ANP), this study offers an approach to assessing mountain olive grove ecosystem services provision. Based on three possible scenarios or alternatives, ANP provides data to determine the management system that has the most impact to provide ecosystem services. The results could supply technical data to support policy decision-making for the development of rural areas.
\end{abstract}

Keywords: Multifunctionality, Ecosystem Services, Mountain Olive Grove, Analytic Network Process, Common Agricultural Policy.

\section{Introduction}

In recent years, the multifunctionality of agricultural and forestry systems has been increasingly gaining significance and has become one of the main objectives in the design of policies such as the Common Agricultural Policy (CAP) (Kallas et al., 2006; Gallardo-Cobos and Ceña-Delgado, 2009; Moreno et al., 2014). This growing interest is motivated by the need to go beyond a mono-criteria and productivity vision of agricultural and forestry systems, towards a more holistic vision in which not only econom- ic but also social and environmental aspects are taken into account in accordance with the concept of sustainable development described in the Brundtland Report (the World Commission on Environment and Development, 1987).

In this context of multifunctionality, the achievements of the UN Millennium Ecosystem Assessment (MA) project in 2003 are of great significance. The results show the importance of quantifying and valuing the ecosystem services provided by each individual ecosystem on the planet. The importance of this lies in the close

\footnotetext{
* Department of Forest Engineering, School of Agricultural and Forestry Engineering, University of Córdoba, Rabanales Campus, Córdoba, Spain.

** Department of Agricultural Economics, School of Agricultural and Forestry Engineering, University of Córdoba, Rabanales Campus, Córdoba, Spain.

Corresponding author: pedro.sanchez@uco.es.
} 
relationship between ecosystem services and human well-being, taking into account both goods and services with and without a market value; the latter of which is not frequently included in policy design (Daily, 1997; MA, 2003; Balvanera and Cotler, 2007; Boyd and Banzhaf, 2007; Pascual et al., 2010; TEEB, 2010).

The MA has given rise to numerous studies that aim to assess ecosystem services provision in order to highlight its significance and contribution to decision making (Daily et al., 2009; Maes et al., 2012; Crossman et al., 2013). There are numerous initiatives by governments, NGOs and international financial institutions that are involved in promoting ecosystem services assessment in an attempt to link results and public policy design (UK National Ecosystem Assessment 2014). However, despite growing awareness and progress, there are still difficulties associated with linking assessment results to investment decision-making (Knight et al., 2008; MacDonald et al., 2014). One of the reasons these difficulties still exist is because of the lack of data required to develop an assessment at a local level (Pandeya et al., 2016).

A major innovation of MA in relation to other assessment tools is that it can be developed at various scales - local, watershed, regional, national, and global - on the understanding that natural and human drivers of change, as well as the biophysical processes that determine the ecological integrity and resilience of ecosystems, are manifested at different spatial and temporal scales (MA, 2003; EME, 2011).

In the context of Spain, MA assessment reports performed on a national as well as a regional scale in Andalusia, have highlighted the close links between ecosystem conservation and human quality of life, and warn that important aspects of well-being are being seriously affected by the progressive degradation of terrestrial and aquatic ecosystems (EME, 2011; Montes and García, 2012). The reports specify that not only are natural ecosystems capable of providing services, but that agroecosystems also have the same potential. This is due to the fact that agroecosystems have been modified to provide food and fibre, have maintained a certain level of ecological integrity, and have a close inter- dependent relationship with human beings, all of which affords significant potential to provide regulating (water regulation, $\mathrm{CO}_{2}$ fixation) and cultural services (landscape, local knowledge) (MA, 2005; Swinton et al., 2007; EME, 2011). Empirical studies on the trade-offs between agricultural production and ecosystem services production reveal a "win-win" relationship in both directions. Relatively small changes in agricultural management practices can achieve balance by ensuring both food provision and service provision in agroecosystems (Garbach et al., 2016). These results can help in decision-making when deciding on the best way to implement multifunctional agriculture in order for crop yields and ecosystem services provision to be maintained or increased.

These questions become more relevant in the case of traditional agroecosystems. Owing to its characteristics, the mountain olive grove is an agroecosystem with a marked multifunctionality and significant potential to provide ecosystem services benefits to the population. This type of olive grove, despite low yields in comparison to other systems, is renowned for its capacity for biodiversity conservation, rural population retention, the conservation of local production systems, the generation of high-value agricultural landscapes, and the revaluation of cultural heritage, among others (Kallas et al., 2006; Arriaza and Nekhay, 2010; Rocamora et al., 2013). However, the crisis currently faced by mountain olive groves, caused largely by lack of profitability, the design and implementation of misguided policies, poor land husbandry, and inadequate management, put the provision of these services in danger, which implies serious consequences for the environment and society at large (Rocamora-Montiel et al., 2014; Sanz-Cañada et al., 2015).

The objective of this paper is to highlight, through the identification and holistic assessment of mountain olive grove ecosystem services, the impact of management systems on the greater or lesser provision of this type of services. The aim is for the results to be considered by decision-makers in the development of public policies for rural areas. The assessment is framed within the scope of the MA, and is performed locally in the region of Los Pedroches, 
located in the north of the province of Córdoba, Andalusia (Spain), where this crop plays a key role, both economically and socially.

To this end, based on the opinion expressed by a group of expert respondents, an assessment was performed using the multi-criteria decision-making technique Analytic Network Process (ANP). More qualitative than quantitative, the assessment was based on the practice of three alternatives or management systems: ecological, conventional, and abandonment. The significance of this research is further increased by the fact that within the EU policies implemented in rural areas are increasingly focused on and targeted at supporting ecosystem service provision generated by agroecosystems.

\section{Conceptual framework}

\subsection{Ecosystem services}

Although the concept of ecosystem services was not defined until the late 1990s, many authors drew attention to environmental problems arising from human activity in relation to nature long before; highlighting the importance and diversity of the services provided by ecosystems to humanity, as well as the high costs involved, and even the impossibility, of replacing them (Westman, 1977; Ehrlich and Mooney, 1983). Consequently, following the emergence of the environmental movement in the 1960s, in the 1970s and 1980s important studies were launched on the environment and ecosystems and their relationship to human well-being, which in one way or another, contributed to the development of the concept of ecosystem services (Daly, 1977; Westman, 1977; Ehrlich and Ehrlich, 1981). Subsequently, in the 1990s, important studies emerged in this area on the role played by ecosystems in the production of ecosystem services (Daily et al., 1997; Costanza et al., 1998).

Since the beginning of the new millennium, there has been certain consensus on the importance of human activity, particularly in agriculture, not only in the use and transformation of ecosystem services, but also in its contribution to the production of these services (Wunder, 2005; FAO, 2007; Engel et al., 2008; Gordon et al., 2010). As such, this study, within the framework of environmental economics, which considers that humans, and in particular farmers, contribute to the production of ecosystem services (Aznar and Pierret-Cornet, 2003). Agroecosystems are actively managed by humans to optimise food, fibre and fuel provisioning. These ecosystem services, recently classified as provisioning services by the MA, depend, in turn, on a support network and regulating services as essential to production.

Based on these questions, and from a more operational and practical perspective, the theoretical framework developed within the MA project defines ecosystem services as the benefits people obtain from ecosystems (MA, 2003) or as ecosystem processes that directly or indirectly support human well-being (MA, 2005). Owing to its simplicity, this is the most practical definition for decision-makers, and is the most widely recognised and used definition in scientific literature. In short, the concept of ecosystem services makes it possible to directly associate natural capital with human well-being, thus closing the cycle of interactions between human activity and ecosystems through the drivers of change (Figure 1).

As shown in Figure 1, indirect drivers of change, such as demographic and economic drivers, generate direct drivers of change, which affect ecosystem and therefore human well-being through the greater or lesser provision of ecosystem services (MA, 2005; Montes and García, 2012). These interactions (which can occur on different spatial and temporal scales) can be influenced by strategies, policies and management models in order to promote a greater provision of ecosystem services (EME, 2011; Montes and García, 2012).

\subsection{Ecosystem services assessment}

At least two types of ecosystem services assessments can be identified in research literature: i) qualitative assessments, based primarily on the opinion of expert respondents and/ or users (Burkhard et al., 2012; Paudyal et al., 2015); and ii) quantitative assessments that usually require biophysical results to be measured 


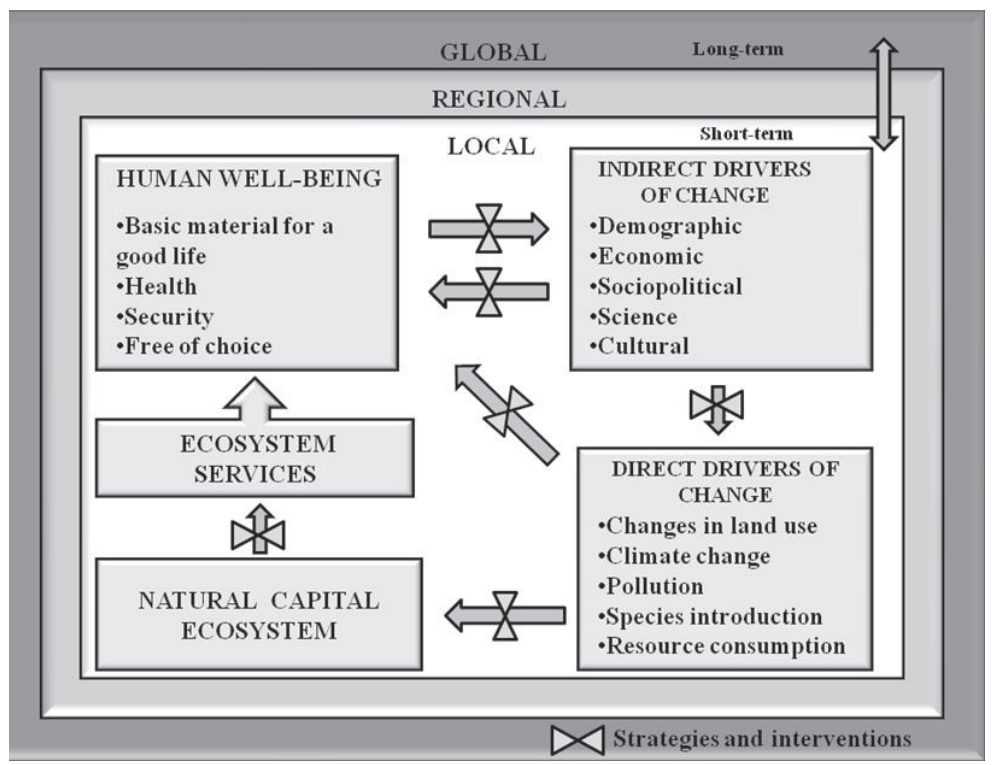

Figure 1 - Ecosystem Services conceptual framework.

Source: MA (2005).

in situ (Nelson et al., 2009; Raudsepp-Hearne et al., 2010). Qualitative assessments can provide valuable data that does not necessarily appear in quantitative assessment data, and can be useful for preliminary planning, understanding general trends, and making policy recommendations. However, on some occasions, they can be somewhat subjective and prone to errors depending on expert knowledge and experience in a particular context (Paudyal et al., 2015). Quantitative assessments are often more precise, and are useful for planning in decision-making, and for establishing ecosystem services payment mechanisms. Nevertheless, as highlighted by some authors, it has been observed that in many of these assessments the analysis focuses on a very specific aspect of the problem, which is addressed in depth by way of complex mathematical models. The result of this is that not all of the important parts of the problem are sufficiently taken into account, so in many cases these models prove to be mathematically sophisticated, but contextually simple (Darnhofer, 2014).

Whatever the type of assessment performed and the advantages or disadvantages they may present, some authors highlight the need to propose a framework for a holistic analysis that takes into account issues such as power relations and governance, in order to encompass the complex- ity and diversity of the social and institutional contexts in which ecosystem services operate (Muradian et al., 2010). In this regard, Barnaud et al. (2011) highlight the need to develop methods aimed at confronting and integrating the diversity of actors' perceptions, interests and knowledge about ecosystem services and dynamics. In a similar vein, the objective behind the study performed by Barala et al. (2016) is precisely to improve the communication, awareness and local participation of stakeholders in ecosystem services provision. Taking stakeholders into account in the analysis, and the context in which they operate, is vital given that they will have different perspectives and could, therefore, also attribute different values to the services provided by ecosystems (Hein et al., 2006). As a result, some authors highlight the importance of not only gathering the opinion of local actors who participate as expert respondents, but also of expert researchers whose knowledge generation can be targeted at providing data for policy decision-makers (de Chazal et al, 2008; Barnaud et al., 2011).

The analysis and assessment of ecosystem services is, therefore, an exceptionally complex task to undertake. This is fundamentally due to the existence of the numerous cause-effect relationships that exist between different ecosystem services, and between ecosystem services and 
the environment in which they operate. As a result, in order to perform an ecosystem services assessment a holistic approach is highly recommended given that it takes into account the multifunctionality of the system, as well as the interdependence established between its different elements (Mendoza and Martins, 2006).

Amongst the many methodologies that incorporate a holistic approach, it is important to highlight the multi-criteria analysis (MCA) techniques (Wam et al., 2016). These analysis techniques, ANP in particular, enable the holistic and transversal assessment required in this type of research by reflecting the opinion of two of the main agents that should be taken into account in decision-making for the design of public policies: i) researchers from a wide range of specialties (rural development, olive growing, hydrology, etc.), and ii) local experts from the region (farmers and managers). The methodology used in this study is based on this type of technique and contemplates all the considerations and premises noted above.

\section{Methodology}

\subsection{Study scope}

The region of Los Pedroches is located in the north of the province of Córdoba, on the border of Andalusia with Castilla-La Mancha and Extremadura (Figure 2). The average population density in the area is low, $24.58 \mathrm{pop} / \mathrm{km}^{2}$, which is less than half the average of the province of Córdoba (58.43 pop $\left./ \mathrm{km}^{2}\right)$, which in turn is one of the lowest in Andalusia ( $96.46 \mathrm{pop} / \mathrm{km}^{2}$ ) (SIMA, 2016). The Los Pedroches mountain olive grove landscape consists of a combination of Mediterranean flora, in different stages of maturity, and olive groves, which gives rise to a mosaic-like structure of high ecological value.

The olive grove under study, which covers approximately $17,901 \mathrm{ha}$., occupies $5 \%$ of the region's total surface-area. These 150-year old rainfed plantations have an average density of over 130 olive trees/ha. The climate is characterised by its seasonality, with average rainfall of $600 \mathrm{~mm}$ distributed between October and May, and a severe water deficit during the summer
Figure 2 - Location of the Los Pedroches mountain olive groves.

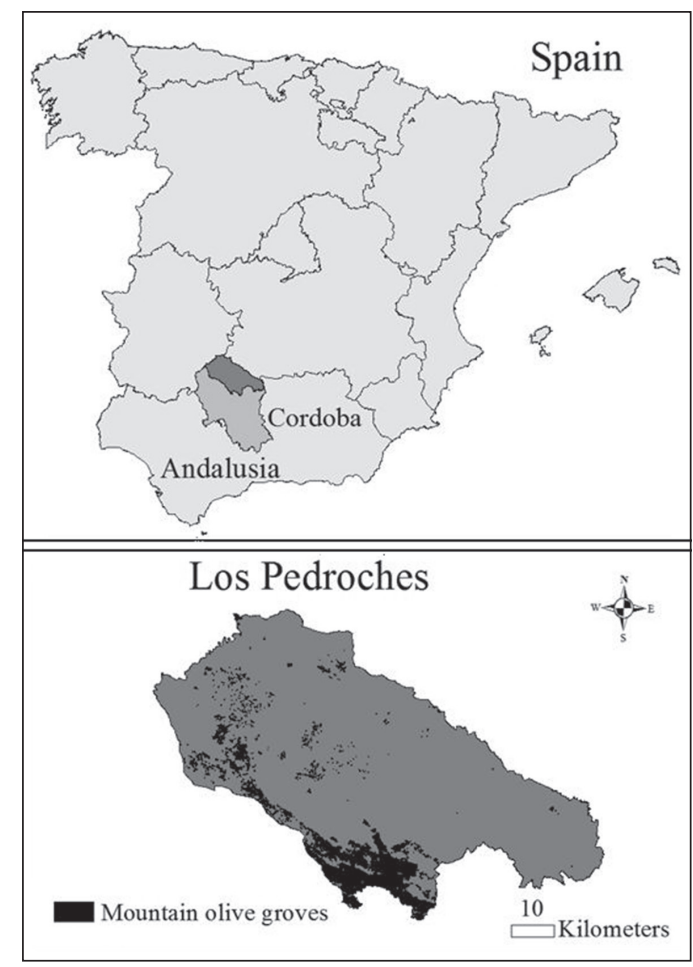

Source: The authors based on the Map of Uses and Vegetation Soil Cover in Andalusia (MUCVA) 19561999-2003-2007, scale 1: 25,000. Andalusia Environmental Data Network (REDIAM). Ministry of Environment - Regional Government of Andalusia.

months. According to the bioclimatic classification devised by Rivas-Martínez (2004), this region corresponds to the "Meso-Mediterranean" belt. The, primarily, leptosol soils are shallow and poor in organic material, with an acidic $\mathrm{pH}$. These edaphoclimatic limitations determine the low yield of the olive trees of around $1,000 \mathrm{~kg}$ of olives/ha. The mountain olive groves' main characteristic is where they are planted - on very steep slopes, with an average incline of between $30 \%$ and $40 \%$, which means production costs are much higher than those for olive groves planted in lowland areas.

However, the olive grove is a very important economic resource in the region, as it provides work in the form of olive grove harvesting and management, and is an income supplement for families with small farms (between 5 and 30 
ha.). Many owners and managers of larger farms depend solely on olive cultivation. However, the high costs of olive grove harvesting and management, excessively low initial pricing, competition with other more intensive farming, policies that are not overly sensitive to the reality of the olive grove, etc., mean that this agroecosystem is at serious risk of abandonment (Rocamora et al., 2013).

\subsection{Analytic Network Process as an assess- ment method}

The ANP technique was used to perform an assessment of the ecosystem services provided by the Los Pedroches mountain olive groves. ANP was initially proposed by Saaty (2001, 2005) and structures a decision problem as a network in which the interdependencies between all the elements that comprise the problem are contemplated, which, in turn, gives rise to a more approximate modelling of reality. It belongs to the family of multi-criteria decision analysis methods and is a more evolved form of the wellknown Analytic Hierarchy Process (AHP). ANP overcomes the limitations of AHP as regards the hierarchical structure and the assumption of independence between the elements of the system analysed (Saaty and Takizawa, 1986). The complete description of the theoretical and operational bases of the ANP method can be found in Saaty (2001), although the basic steps to follow for the application of the method are summarised below:

\section{1) Modelling the problem as a network}

For the modelling of the problem the decision problem objective must first be determined. Second, relevant elements in the network must then be identified: i) the alternatives proposed for achieving the decision problem objective; ii) the decision criteria through which the alternatives contribute to achieving the decision problem objective. Next, the elements are grouped according to similarity criteria to form clusters (decision clusters and alternatives). Finally, the relationships between the elements that constitute the network are analysed. In order to do so, a matrix of influences like the one used in this study is usually employed (Table 2). In this matrix the rows and columns are formed by all the elements of the network grouped by clusters, so that in the pairwise comparison they take the value of 1 when the element of the row influences the criterion of the column, and 0 when there is no influence.

\section{2) Pairwise comparisons between elements and questionnaire research}

After analysing the relationships between the elements of the network, the next step is to determine the relative priorities between those elements. To that effect, a questionnaire is used to interview experts, which includes questions about all the pairwise comparisons between related elements (those that take the value of 1 in the matrix of influences) with the aim of determining their priorities. As a result, two elements are compared at the same time with respect to a third which acts as a control element. In other words, the respondent is confronted with pairwise comparisons of elements that influence a third and should only indicate which of the two elements, and to what intensity, most influences the third element of control. The assessment of the intensity of preference is performed using the fundamental scale of absolute numbers devised by Saaty (2001), whose meaning is: 1 «Two activities contribute equally to the objective»; 3 «Experience and judgement slightly favour one activity over another»; 5 «Experience and judgement strongly favour one activity over another»; 7 «An activity is favoured very strongly over another; its dominance demonstrated in practice», and 9 «The evidence favouring one activity over another is of the highest possible order of affirmation». As in AHP, weighted values are usually obtained by calculating the eigen vector for the value judgment matrix for each group of pairwise comparisons.

\section{3) Obtaining the unweighted or initial superma- trix}

In this step, the weights obtained from the reciprocal matrixes are introduced into the supermatrix that contains all the network clusters and nodes and represents its interrelationships. This first supermatrix is called the initial supermatrix. 
4) Obtaining the weighted or stochastic supermatrix

In this step, the cluster weights should be calculated in order to weight the initial supermatrix. Once the cluster matrix weight has been generated, the initial supermatrix can be weighted by multiplying the cluster weights matrix by an initial supermatrix. The matrix obtained by means of this operation is known as the weighted or stochastic supermatrix.

\section{5) Obtaining the limit supermatrix}

The weighted supermatrix is raised itself to powers until the values of the rows converge to the same value for each column of the matrix. This mathematical operation is performed in order to capture the transmission of influence along all possible paths of the supermatrix. The resulting matrix is called the limit supermatrix. Every column of the limit supermatrix shows the same solution of the network problem: the global importance or priority of each element of the network.

\subsection{Implementing the method in the case study}

In recent years, there has been an increase in scientific work in different fields of knowledge that uses ANP in case studies (Sipahi and Timor, 2010). However, its implementation in the field of ecosystem goods and service assessment has not been overly prolific. This technique has been used at a regional and local level by Arriaza and Nekhay (2010) to aggregate the opinions of citizens and experts regarding mountain olive grove erosion risk; by Pérez and Pérez et al. (2013) for the assessment of the territorial externalities of two olive oil Protected Designations of Origin (PDO), and by Villanueva et al. (2014) to analyse the production of public goods in irrigated agroecosystems.
Based on this literature, and taking into account the particularities of the case study analysed, and also bearing in mind the basic stages of ANP described in the previous section, the method was implemented in the stages described in the following sections.

\section{1) Selection of ecosystem services, alternatives and design of the network structure}

In this study, the network consists of the following elements (see Table 1):

- The criteria correspond to ecosystem services provided or potentially provided by the Los Pedroches mountain olive groves. The MA conceptual framework employed in Spain (EME, 2011) ${ }^{1}$ was used as the basis for the identification of ecosystem services and the design of the network structure. As a result, three criteria clusters were created that group ecosystem services as follows: i) provisioning; ii) regulating; and iii) socio-cultural.

- The alternatives are formed by the management systems contemplated in the analysis: i) ecological management; ii) conventional management; and iii) abandonment. These three alternatives are integrated within the alternative cluster.

Once the ecosystem services and the alternatives to be assessed were identified, their interdependent relationships were analysed. To this end, a matrix of influences was used (see Table 2), which was generated using a deliberative process in cooperation with experts who are knowledgeable about the object of study. As a result, the network structure is represented as shown in Figure 3.

\section{2) Pre-test implementation and final question- naire design}

The questionnaire, which included the items to be answered by the expert respondents, was produced once the network was defined and the

\footnotetext{
${ }^{1}$ Currently, the three most popular methodologies used in ecosystem services classification are those used by the Common International Classification of Ecosystem Services (CICES), The Economics of Ecosystems and Biodiversity (TEEB), and the Millennium Ecosystem Assessment (MA) (Brouwer et al., 2013). In this study we have used the MA methodology, given that it is the most widely accepted due to its international origin and greater political impact (Camacho and Ruiz, 2011; Brouwer et al., 2013). In addition, this classification has been adopted by the MA both in Spain (EME, 2011) and in Andalusia (Montes and García, 2012).
} 
Table 1 - Description of the ecosystem services and management systems of the Los Pedroches mountain olive grove.

\begin{tabular}{|c|c|c|}
\hline Cluster & Criteria & Description \\
\hline \multirow{3}{*}{ 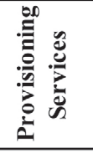 } & S1. Food quality & Quantity and quality of healthy foodstuffs for human consumption. \\
\hline & S2. Water quality & Supply of water fit for human consumption, waste and contamination-free. \\
\hline & S3. Gene pool & $\begin{array}{l}\text { Genetic diversity stock of species and breeds that favours the provisioning of products and } \\
\text { offers opportunities for adaptation to future conditions. }\end{array}$ \\
\hline \multirow{5}{*}{ 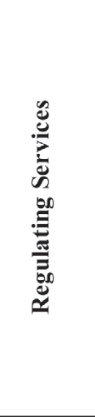 } & $\begin{array}{l}\text { S4. Climate regulation and } \\
\mathrm{CO}_{2} \text { fixation }\end{array}$ & $\begin{array}{l}\text { Capacity to regulate climate at a local and global level via } \mathrm{CO}_{2} \text { fixation, milder temperatures, } \\
\text { higher percentage of moisture in the air, and more regular rainfall. }\end{array}$ \\
\hline & S5. Water regulation & $\begin{array}{l}\text { Capacity of the olive grove to regulate water circulation in river basins favouring infiltration } \\
\text { and replenishment of aquifers, cushioning the effects of intense rainfall that generate large } \\
\text { gullies, and acting as a purification filter. }\end{array}$ \\
\hline & $\begin{array}{l}\text { S6. Soil crosion regulation and } \\
\text { improvement }\end{array}$ & $\begin{array}{l}\text { Regulation of soil loss due to erosion using crop cover to reduce runoff, cushion the impact of } \\
\text { rain on the soil, retain moisture, avoid river and reservoir silting. Increase soil fertility by } \\
\text { improving physical-chemical properties. }\end{array}$ \\
\hline & S7. Wildfire mitigation & Capacity of ecosystems to reduce fire risk and related dangers. \\
\hline & S8. Biodiversity conservation & $\begin{array}{l}\text { Maintain diversity of living organisms and ecosystems via ecological processes that create and } \\
\text { indirectly regulate the provision of other services that contribute to human well-being. }\end{array}$ \\
\hline \multirow{4}{*}{ 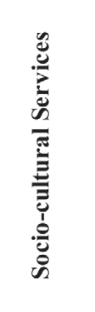 } & $\begin{array}{l}\text { S9. Local knowledge and } \\
\text { cultural heritage }\end{array}$ & $\begin{array}{l}\text { Knowledge held by the local population about the traditional forms of use and management of } \\
\text { regional resources and the existence of a sum of traditions, customs and infrastructures } \\
\text { characteristic of the region. }\end{array}$ \\
\hline & S10. Landscape & $\begin{array}{l}\text { Provision of a landscape with characteristic elements of the region which make it aesthetically } \\
\text { pleasing. }\end{array}$ \\
\hline & S11. Recreation and tourism & Provision of a landscape that facilitates recreational and tourist activities. \\
\hline & $\begin{array}{l}\text { S12. Rural population } \\
\text { retention and job creation }\end{array}$ & $\begin{array}{l}\text { Capacity of the olive grove to maintain an active, cohesive and balanced rural population, } \\
\text { creating employment and retaining young people in the region. }\end{array}$ \\
\hline \multirow{3}{*}{ 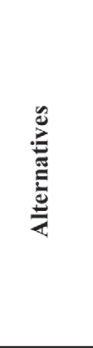 } & Al. Ecological & $\begin{array}{l}\text { Production system that aims to produce healthy and quality foodstuffs, combining production } \\
\text { with eco-friendly agriculture practices with the aim of ensuring the protection of natural } \\
\text { resources (soil, water, biodiversity, etc.). Characterised by the non-use of synthetic chemical } \\
\text { products, and the use of organic fertilisers, modified minerals, natural plague controls and } \\
\text { other inputs for fertilisation and pest control. }\end{array}$ \\
\hline & A2. Conventional & $\begin{array}{l}\text { A non-ecological production system in which the use of synthetic chemical fertilisation and } \\
\text { pest control products is permitted in the olive grove with the aim of maximising olive } \\
\text { production. }\end{array}$ \\
\hline & A3. Abandonment & $\begin{array}{l}\text { This alternative involves not implementing any cultivation practices, but allowing the } \\
\text { abandoned land, where the olive trees are planted, to evolve according to natural dynamics. }\end{array}$ \\
\hline
\end{tabular}

relationships between its elements established. Examples of the items in the questionnaire are: "On the provision of FOOD QUALITY, which service, A or B has more influence and to what extent?" The answer format, as mentioned above, was based on Saaty's fundamental scale (2001). Once the questionnaire was produced, a pre-test was performed. This consisted of implementing the pilot questionnaire in conjunction with the experts consulted in order to determine the network. This stage served to verify the interviewees' understanding of the questions and the validity of the answers obtained, as well as to reduce the number of interrelations contemplated at the be- ginning; disregarding those that were considered second level in the absence of consensus between all the experts consulted. The final questionnaire consisted of 178 items aimed at collecting pairwise comparisons between elements in order to determine: i) the influences between ecosystem services within the same cluster; ii) the influences between criteria clusters; iii) the influences of alternatives on ecosystem services; iv)the influences of ecosystem services on alternatives.

\section{3) Selection of expert respondents}

The design of the study entailed interviewing, on the one hand, local experts, those with 
Table 2 - Matrix of influences for the case study.

\begin{tabular}{|c|c|c|c|c|c|c|c|c|c|c|c|c|c|c|c|}
\hline \multirow{2}{*}{$\begin{array}{l}\text { Clusters } \\
\text { Criteria }\end{array}$} & \multicolumn{3}{|c|}{ Provisioning Services } & \multicolumn{5}{|c|}{ Regulating Services } & \multicolumn{4}{|c|}{ Socio-cultural Services } & \multicolumn{3}{|c|}{ Alternatives } \\
\hline & S1 & S2 & S3 & S4 & S5 & S6 & S7 & S8 & S9 & S10 & S11 & S12 & Al & A2 & $\mathbf{A 3}$ \\
\hline \multicolumn{16}{|c|}{ Provisioning } \\
\hline S1 & & 0 & 0 & 0 & 0 & 0 & 0 & 0 & 1 & 0 & 1 & 1 & 1 & 1 & 1 \\
\hline S2 & 1 & & 0 & 1 & 0 & 1 & 0 & 1 & 0 & 1 & 1 & 1 & 1 & 1 & 1 \\
\hline S3 & 1 & 0 & & 1 & 0 & 0 & 0 & 1 & 1 & 1 & 0 & 0 & 1 & 1 & 1 \\
\hline \multicolumn{16}{|l|}{ Regulating } \\
\hline S4 & 0 & 1 & 1 & & 1 & 1 & 0 & 1 & 0 & 1 & 0 & 0 & 1 & 1 & 1 \\
\hline S5 & 1 & 1 & 0 & 1 & & 1 & 1 & 1 & 0 & 1 & 0 & 0 & 1 & 1 & 1 \\
\hline S6 & 1 & 1 & 0 & 1 & 1 & & 0 & 1 & 0 & 1 & 0 & 1 & 1 & 1 & 1 \\
\hline S7 & 0 & 1 & 1 & 1 & 1 & 1 & & 1 & 0 & 1 & 0 & 0 & 1 & 1 & 1 \\
\hline S8 & 1 & 0 & 1 & 1 & 0 & 1 & 0 & & 1 & 1 & 1 & 1 & 1 & 1 & 1 \\
\hline \multicolumn{16}{|c|}{ Socio-cultural } \\
\hline S9 & 1 & 0 & 1 & 0 & 1 & 1 & 1 & 1 & & 1 & 1 & 0 & 1 & 1 & 1 \\
\hline S10 & 0 & 0 & 0 & 0 & 0 & 0 & 0 & 0 & 0 & & 1 & 1 & 1 & 1 & 1 \\
\hline S11 & 1 & 0 & 0 & 0 & 0 & 0 & 1 & 1 & 1 & 0 & & 1 & 1 & 1 & 1 \\
\hline $\mathrm{S} 12$ & 0 & 0 & 0 & 0 & 1 & 1 & 1 & 0 & 1 & 1 & 1 & & 1 & 1 & 1 \\
\hline \multicolumn{16}{|c|}{ Alternatives } \\
\hline A1 & 1 & 1 & 1 & 1 & 1 & 1 & 1 & 1 & 1 & 1 & 1 & 1 & 1 & 1 & 1 \\
\hline A2 & 1 & 1 & 1 & 1 & 1 & 1 & 1 & 1 & 1 & 1 & 1 & 1 & 1 & 1 & 1 \\
\hline $\mathbf{A} 3$ & 1 & 1 & 1 & 1 & 1 & 1 & 1 & 1 & 1 & 1 & 1 & 1 & 1 & 1 & 1 \\
\hline
\end{tabular}

Source: The authors based on expert opinion.

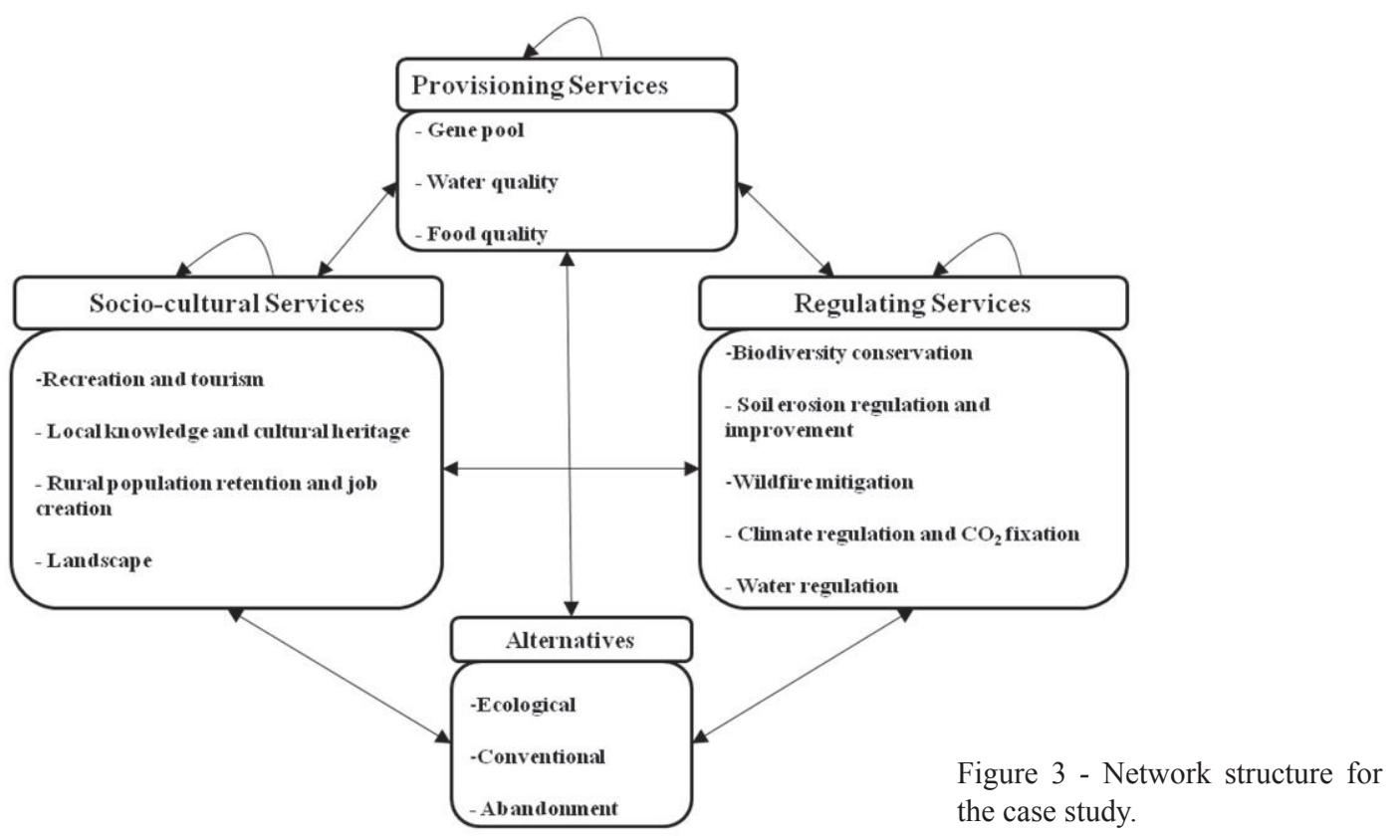

sound knowledge of the region and, on the other, researchers, those with recognised experience in the field of ecosystem services provision in mountain olive groves. Given the characteristics of the methodology followed (which requires a sound technical knowledge and availability to complete long questionnaires), the number of experts available to consult is often limited, usually around 6 to 15 respondents (Villanueva et al., 2014; Sánchez-Zamora et al., 2017). For this study, a total of 16 expert respondents were interviewed; 8 local experts who were knowledgeable about the region (olive growers, owners, managers, etc.) and 8 researchers who were experts in different fields (erosion and crop cover, agrosilvopastoral sys- 
Table 3 - Relative values of ecosystem services generated by the Los Pedroches mountain olive groves.

\begin{tabular}{lc}
\hline \multicolumn{1}{c}{ ECOSYSTEM SERVICES } & SCORE (\%) \\
\hline PROVISIONING SERVICES & $\mathbf{2 9 . 2}$ \\
\hline S1. Gene pool & 8.9 \\
S2. Water quality & 9.3 \\
S3. Food quality & 11.0 \\
REGULATING SERVICES & $\mathbf{4 1 . 3}$ \\
\hline S4. Biodiversity conservation & 10.8 \\
S5. Soil improvement and erosion regulation & 10.4 \\
S6. Wildfire mitigation & 7.0 \\
S7. Climate regulation and $\mathrm{CO}_{2}$ fixation & 3.7 \\
S8. Water regulation & 9.4 \\
SOCIO-CULTURAL SERVICES & $\mathbf{2 9 . 5}$ \\
\hline S9. Recreation activities and tourism & 6.1 \\
S10. Local knowledge and cultural heritage & 9.9 \\
S11. Rural population retention and job creation & 9.0 \\
S12. Landscape & 4.5 \\
\hline
\end{tabular}

tems, rural development, olive cultivation and agricultural sustainability), and knowledgeable about the object of study.

\section{4) Obtaining and processing the results}

The results were extracted from the unweighted, weighted and limit super matrices for each expert using Super Decisions version 2.2.6 support software, which was specifically developed to implement ANP (Saaty, 2003). Subsequently, the results were obtained for each one of the 16 expert respondents. It is important to note here that, in every interview, the experts' answers were automatically reviewed by the programme in order to avoid inconsistencies, and to ensure that the calculation of the model was totally correct (inconsistency ratio less than 0.1 ).

\section{5) Aggregation of results}

Finally, in order to obtain aggregate results that reach a consensus on the combined knowledge of the panel of expert respondents, the aggregation of individual priorities (AIP) method was performed using the method of geometric mean.

\section{Results and discussion}

The implementation of the methodology described in the previous section facilitated the assessment of the ecosystem services generated by the mountain olive grove, and determined the management system that provide a greater provision of those ecosystem services.

Based on the opinions expressed by the experts interviewed, Table 3 shows the score obtained for each cluster (provisioning, regulating and socio-cultural), as well as those obtained for each of the 12 ecosystem services contemplated in the analysis. The score of each individual ecosystem service is the result of its capacity to influence the rest of the elements in the system and its contribution to human well-being.

In the light of the results, it can be confirmed that, in the case of the clusters or types of ecosystem services in mountain olive groves, the expert respondents value the provisioning of Regulating Services (41\%) more than Socio-cultural Services (30\%) and Provisioning Services (29\%).

Studying the ecosystem services analysis in detail reveals that the service with the highest relative weight is S3 Food Quality (11\%). Indeed, one of the main objectives of the region's olive growers is their commitment to quality food production and, in particular, olive oil. In order to ensure a minimum level of income, given that the olive groves are low-yield, owners often follow a strategy of differentiation by way of quality.

The second most valued service is S4Biodiversity conservation (10.8\%). Expert respondents, in the same line as other studies (Altieri et al., 1999; Gómez, 2010) express the important role that this service plays in the sustainability of agroe- 
cosystems. In fact, as can be seen in the matrix of influences (Table 2) this service has multiple interdependent relationships with the rest of the ecosystem services included in the analysis.

The third service with the highest relative weight is S5Soil improvement and erosion regulation $(10.3 \%)$. This service is closely related to $S 8$ Water regulation $(9.4 \%$ ) and $S 2$ Water quality $(9.3 \%)$, which also have significant relative values. Experts regard these services as fundamental due to the risk of erosion that exists in certain areas of the region, mainly in river basins that supply reservoirs. These results, similar to those obtained by Pérez and Pérez et al. (2013) are in slight contrast with studies performed in other types of olive grove other than mountain, where soil improvement and erosion regulation is regarded as one of the principal problems associated with cultivation, erosion, and diffuse pollution (Sanz et al., 2011). The differences found may be due to the traditional characteristics of the mountain olive grove management in Los Pedroches, where livestock are frequently used to regulate crop cover and are kept in the olive groves for a substantial part of the year, which contributes to the fight against erosion (Alonso and Guzmán, 2008; Carbonero et al., 2013).

Socio-cultural services: S10 Local knowledge and cultural heritage (9.9\%), and S11 Rural population retention and job creation ( $9 \%$ ) were also given high relative weights by expert respondents. This reveals the capacity of the agroecosystem analysed to generate employment in disadvantaged areas, in addition to preserving traditional knowledge associated with olive cultivation. In particular, the importance given to S10 Local knowledge and cultural heritage is largely due to the respondents' belief that the existence of local knowledge is fundamental to the provision of other services such as S1 Genepool (8.9\%), S6 Wildfire mitigation (7\%), S9 Recreational activities and tourism (6.1\%), and S12 Landscape (4.5\%).

In reference to the latter service, S12 Landscape, it is interesting to note that although the Los Pedroches olive grove is a unique landscape, this service presents one of the lowest relative weights. One possible explanation is that although it is a service that is influenced by practically all the other services analysed, it has hardly any di- rect influence on the other services itself, as can be observed in the matrix of influences (Table 2).

Finally, the service with the lowest relative weight is $\mathrm{S} 7$ Climate regulation and $\mathrm{CO}_{2}$ fixation $(3.71 \%)$. According to the experts, this is mainly due to the fact that it is a service whose impact is mainly perceived at a global rather than a local level. Moreover, studies on $\mathrm{CO}_{2}$ fixation in olive groves reveal that new plantations, due to their higher growth rate, have more capacity to fix $\mathrm{CO}_{2}$ than older plantations such as those found in Los Pedroches (López, 2012; López et al., 2014).

In relation to which alternative or management system has a greater capacity to provide ecosystem services, Figure 4 clearly shows the preferred system to be Ecological management $(56 \%)$, with a relative weight more than double that given to Abandonment (26\%), and three times greater than that given to Conventional management (18\%). These results coincide with those obtained in studies performed by Sánchez (2003) and Alonso and Guzmán (2008). In these studies, a comparative assessment of ecological and conventional management agricultural sustainability in Los Pedroches was performed, and it was concluded that, in general terms, ecological management, reaches higher levels of sustainability and generates more positive externalities than conventional management.

In order to understand to what extent, the experts believe that each alternative contributes to the generation of each type of ecosystem services, the data from the unweighted matrices can be seen in Figure 5. The answers make it clear that Ecological management is once again the alternative that contributes most to the provision of the three types of ecosystem services: provisioning, regulating and socio-cultural. The results also reflect that Abandonment contributes to a greater extent than Conventional management in the generation of provisioning and regulating services, but not socio-cultural services.

In contrast, Figure 6 reflects which of the three alternatives contributes most to the provision of each of the ecosystem service generated by the mountain olive grove. The results show that in general Ecological management is the best option for the provision of almost every ecosystem services. 

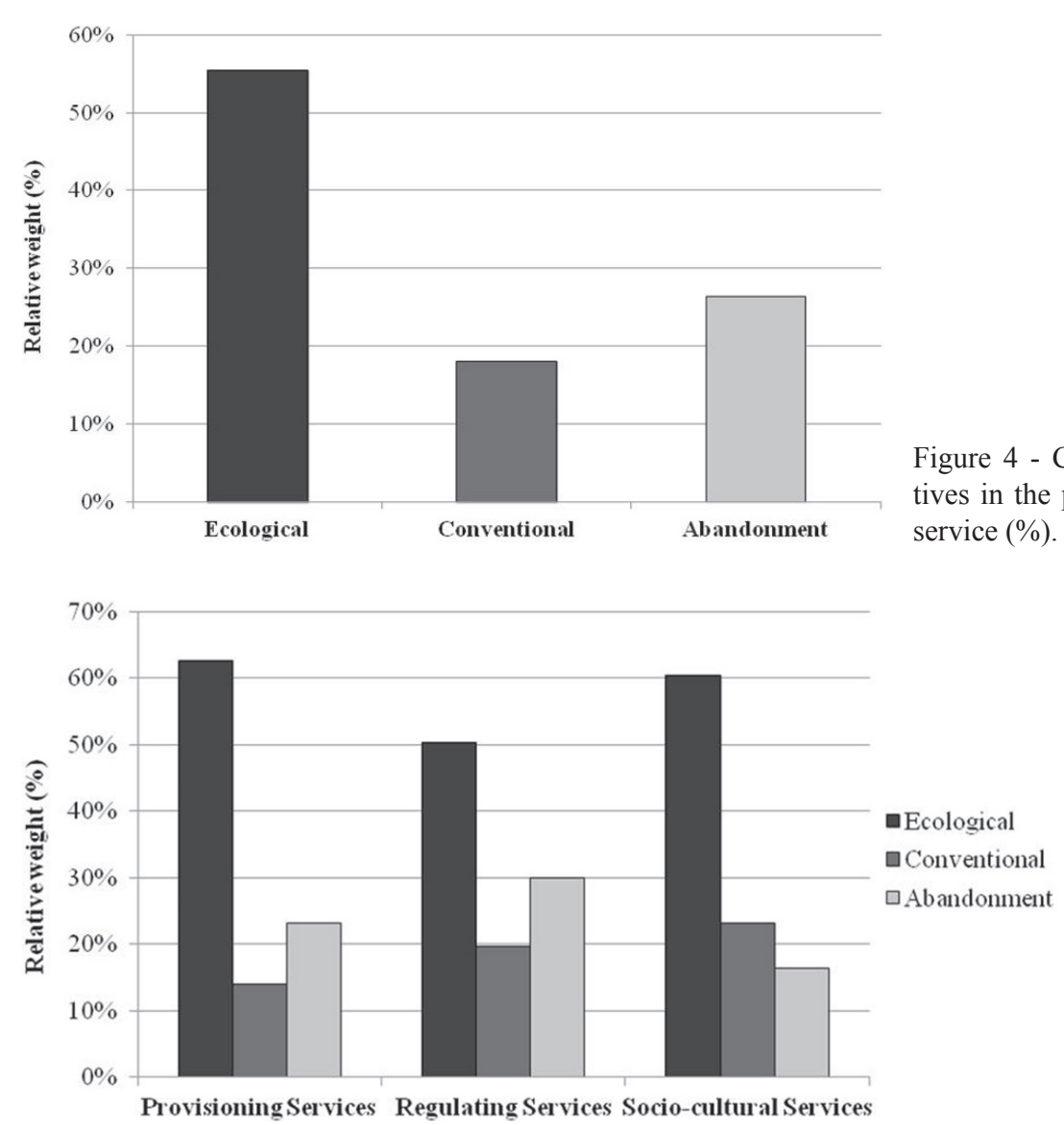

Figure 4 - Contribution of alternatives in the provision of ecosystem service (\%).
In a comparative analysis between Ecological management and Abandonment, it could be significant that even in the generation of regulating services the former contributes more than the latter. However, it is important to note that, in the opinion of the experts, the cultivation techniques used in Ecological management (cover crop, minimum tillage by rows, and using livestock to control crop cover) are more effective in S5 Erosion regulation and S8 Water regulation than scrubland, which, in the first instance, would colonise the olive grove if it were abandoned (Guzmán and Navarro, 2005). Similarly, a mosaic-like landscape with rotational grazing areas in the olive groves, which provide food for wildlife and upland areas that provide shelter, could be much more beneficial for S4 Biodiversity conservation than an abandoned olive grove in which most of the surface-area was occupied by bush (Delibes-Mateos et al., 2013).
At this same level of analysis, it can also be observed that Ecological management, rather than Abandonment, contributes more to the provision of S12 Landscape services. However, this result is in the same line as that reflected in the study performed by Sayadi et al. (2005, 2009), which highlights the preference of the population for mountain agricultural landscapes, such as the Los Pedroches olive groves, given that it is recognised as a unique landscape of historical and cultural importance.

Similarly, it is also worth noting the low capacity of Abandonment to generate socio-cultural services relating to S11 Rural population retention and job creation and $\$ 10$ Local knowledge and cultural heritage, and some provisioning services such as $S 3$ Food quality. In this regard, the experts highlight that, even though Abandonment could be a good option in the environmental field, given that it could 
Figure 6 - Contribution of alternatives in the provision of each ecosystem service (\%).

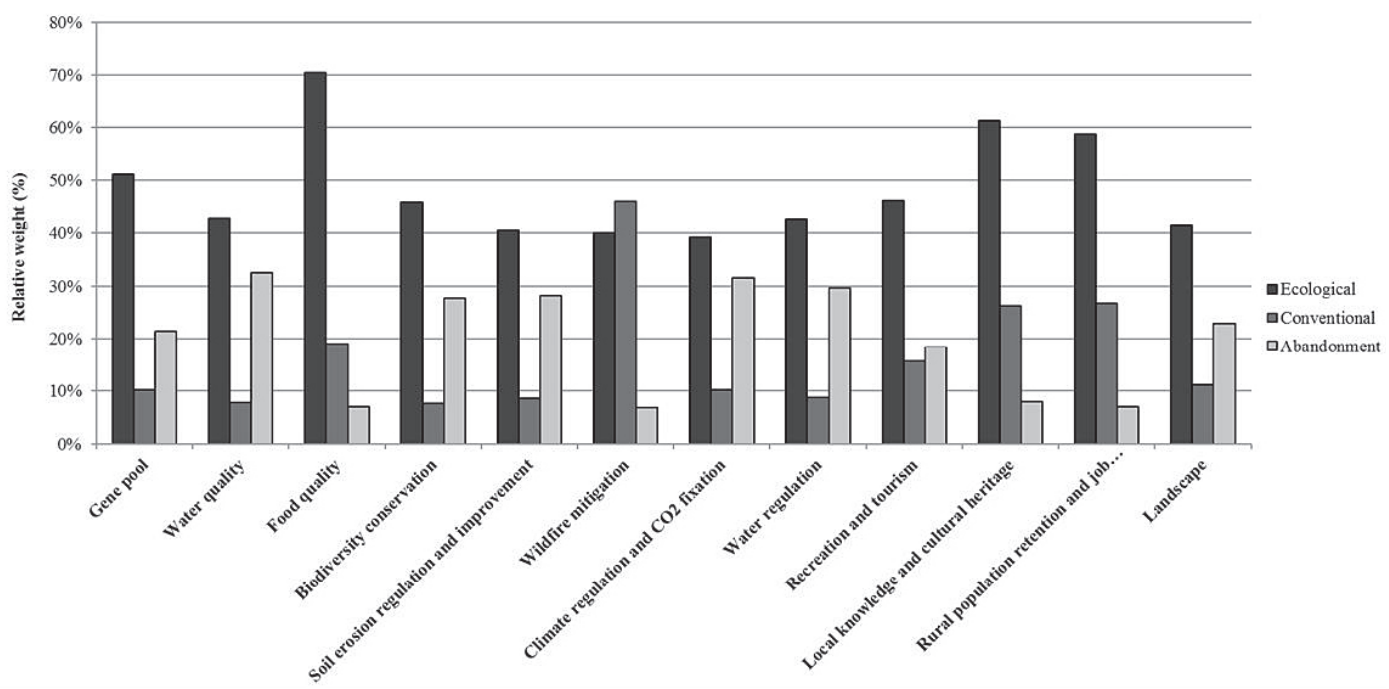

contribute to reducing the risk of erosion and increase water regulation with respect to other alternatives such as Conventional management, in the socioeconomic field it would be less sustainable as it would not have the capacity to create employment or to retain the rural population.

In contrast, in a comparative analysis between Ecological management and Conventional management, it can be seen how the former has greater capacity than the latter to provide services such as $S 11$ Rural population retention and job creation, S10 Local knowledge and cultural heritage, and $S 1$ Gene pool. In the opinion of the experts, this might be due to the fact that although in Conventional management olive oil production is higher, Ecological management endows the product with an added value that can entail a qualitative differentiation which is economically beneficial for olive growers and could ultimately influence job creation. In addition, they highlight that Ecological management is more labour intensive and is based on more traditional tasks that usually require local knowledge. However, it should not be generalised, given that the use of livestock to simplify the task of desvareto or crop cover control would imply a reduction in the work force needed in ecologically managed olive groves with respect to conventionally managed ones.
At another level of analysis, it could be interesting to analyze the differences and similarities that might exist in the responses provided by the two expert groups interviewed. In doing do, it would be possible to analyze to what extent the criteria of the researchers and the opinions of local experts converge in relation to: i) the provision of ecosystem services; and ii) the alternatives that most contribute to provision.

Figure 7 shows the relative weight of each ecosystem service according to the criteria of the two expert groups. The main differences can be seen in: S3 Food Quality, which was given more weight by local experts than by researchers; $S 1$ Gene pool, given more weight by the group of researchers, and S11 Rural population retention and job creation, which again was given more weight by local experts than by researchers. The rest of the ecosystem services do not show significant variations between the two expert groups.

Finally, Figure 8 shows the opinion of each expert group regarding the contribution of each alternative to the provision of ecosystem services. The results obtained show that both groups (local experts and researchers) identify Ecological management as the alternative with the greatest capacity for the provision of ecosystem services in mountain olive groves, followed by Abandonment and Conventional management. The fact that this consensus exists gives greater strength 


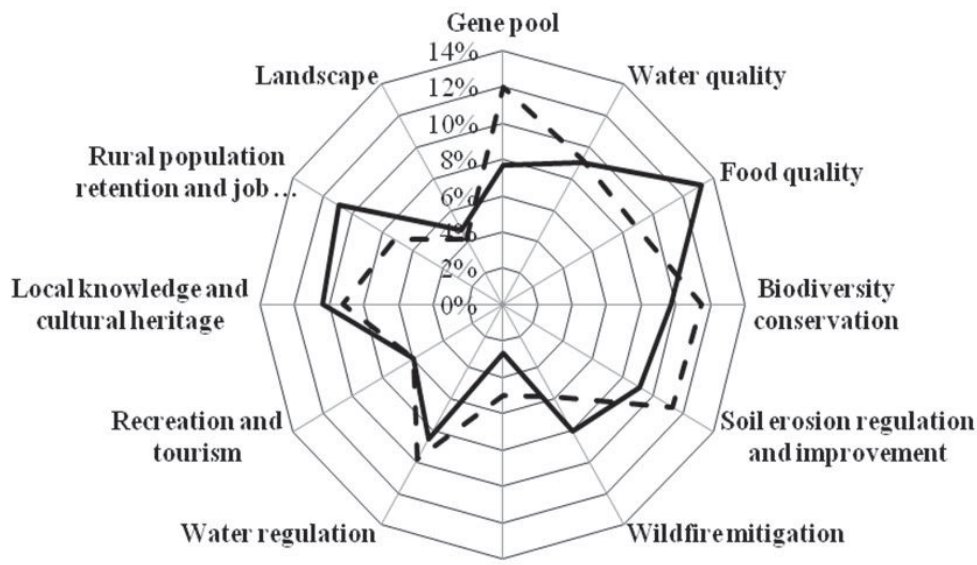

Climate regulation

and $\mathrm{CO} 2$ fixation

Figure 7 - Relative weight of each ecosystem service (local experts vs. researchers).

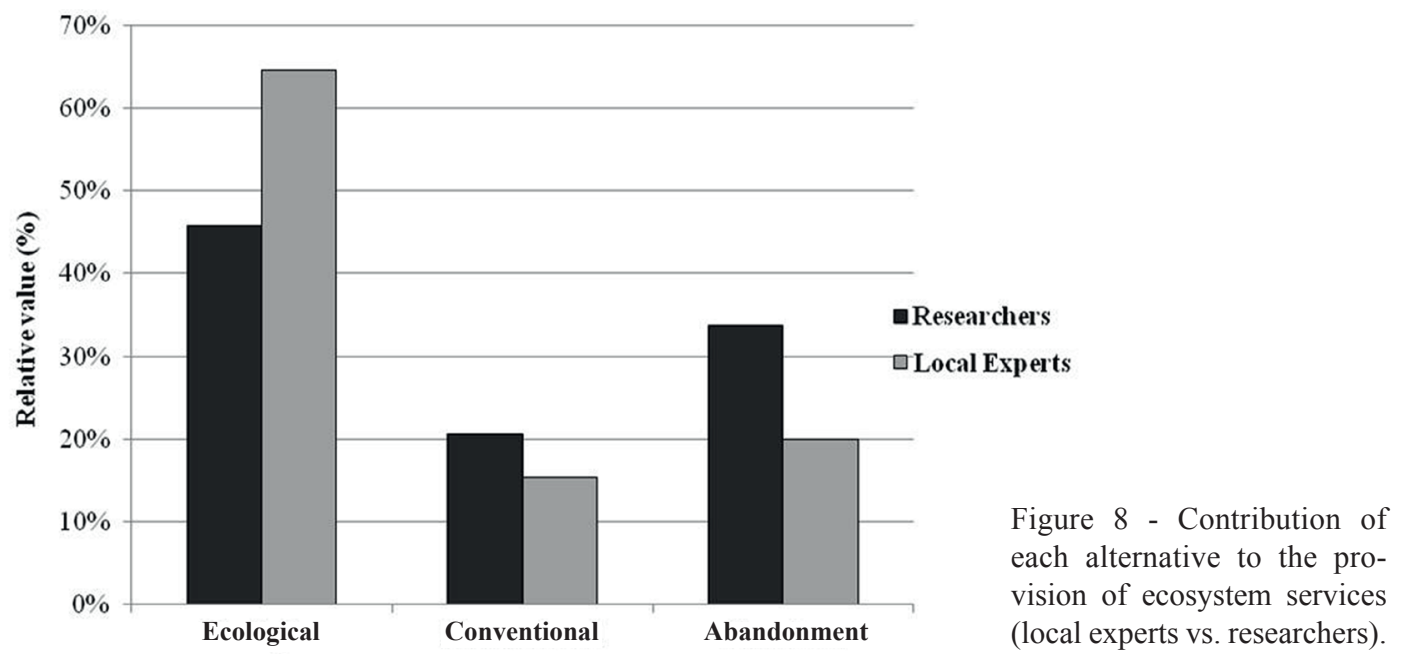

to the results obtained and enables policy recommendations to be made to improve the provision of ecosystem services in rural areas. Political authorities could adopt these recommendations and promote policies based on them to stimulate ecological management. However, many farmers may prefer not to make any changes and continue with the same management system used so far. In this context, in the future it would be interesting to analyze how different strategic behaviors that might emerge between public institutions and stakeholders influence the provision of ecosystem services. To this end, as proposed by Mulazzani et al. (2017), it could be interesting to integrate Bayesian networks and game theory into the analysis of ecosystem services.

\section{Conclusions}

In the field of agroecosystems, the term "ecosystem services" refers to the goods and services that benefit human kind via functions including agriculture, which generates services not only relating to the production of raw materials and food stuff sowing to its very nature as a productive sector, but also other social, territorial and 
environmental functions, associated with its relationship to the social environment, land occupation, and interaction with the environment. This combination of ecosystem services associated with farming is increasingly significant in the context of social welfare, which has contributed in recent years to a substantial change in society's demand for agriculture and the rural environment in the EU. In fact, society expects farmers not only to provide food and fibre, but also other types of goods, such as environmental and socio-cultural services (EC, 2010).

In this context, both the CAP and the Rural Development Policy, as policies at the service of the citizens, have tried to improve their legitimacy in relation to new social demands. In recent reforms both policies have highlighted the need to link aid to the provision of other ecosystem services exclusive of traditional productive services. In this regard, and with the intention of supporting decision-making concerning the most appropriate design and implementation of policy tools, there is a need to identify and assess the provision of these services, mainly in those agroecosystems most challenged by their level of market competitiveness, and those located in disadvantaged and mountain areas with high levels of marginality.

On this basis, in this study an assessment was performed to identify both the main ecosystem services provided by the mountain olive grove, and the management system that most influences this provision. From the results obtained, it can be concluded that the greater or lesser provision of ecosystem services in this type of olive grove depends to a large extent on the type of management used, and that the best of the three alternatives contemplated is Ecological management. In addition, it was established that this alternative is not only the most adequate at a global level, but also for the provision of virtually all ecosystem services. It is therefore recommended that agricultural and rural policy tools targeted at improving the provision of ecosystem services, in this type of agroecosystem, should focus on the promotion of certain practices relating to Ecological management. In fact, in the Andalusia Rural Development Programme for the period 20142020, in the section on measures titled "Agri-environment and Climate" there is a measure that warrants further investigation - «An ecological approach to the mountain olive grove». This is a support measure for olive groves with a gradient of over $20 \%$ and at least $1 \mathrm{ha}$. of land that is committed to maintaining spontaneous crop cover during a certain period of the year. These measures compensate and encourage farmers to carry out adequate management in order to promote "beneficial habits" such as applying minimum tillage techniques and maintaining crop cover for erosion control, leaving scrubland areas between the crop for wildlife shelter, etc.

In addition, the relevance of the results obtained in this analysis for the case study contemplated, legitimates interest in performing similar analyses in other agroecosystems, with the ultimate aim of improving the scope and adaptation of agricultural and rural policy tools, and thus their efficiency in public decision-making. These new assessment analyses could be performed using a methodology similar to the one proposed in this study. The ANP method enabled the holistic and transversal analysis required in ecosystem services assessments. It is a useful method for the modelling of complex problems, given that it takes into account the multiple relationships that are established between the elements that intervene in the system, and sets a preference hierarchy that helps planning and decision making. The implementation of this technique facilitated the incorporation of the opinion of two of the main agents that should be taken into account in the decision-making process for the design of public policies: i) expert researchers in the object of analysis; and ii) local actors who participate as expert respondents.

The authors thank the reviewers for their insightful comments and suggestions on how to improve the manuscript, the experts interviewed for their collaboration, and "ECOVALIA (Asociación Valor Ecológico CAAE)" for awarding this research with "Premio Nacional a la Investigación en Producción Ecológica Núñez de Prado".

\section{References}

Alonso A.M. and Guzmán G.I., 2008. Evaluación comparada de la sostenibilidad agraria en el olivar ecológico y convencional. Agroecología, 1: 63-74. 
Altieri M., 1999. The ecological role of biodiversity in agroecosystems. Agriculture, Ecosystem and Enviroment, 74: 19-31.

Arriaza M. and Nekhay O., 2010. Evaluación social multicriterio del territorio agrícola: el caso del olivar de baja producción. Revista Española de Estudios Agrosociales y Pesqueros, 226: 39-69.

Aznar O. and Perrier-Cornet P., 2003. Les services environnementaux dans les espaces ruraux: une approche par l'économie des services. Economie Rurale, 273-274: 153-168.

Balvanera P. and Cotler H., 2007. Acercamientos al estudio de los servicios ecosistémicos. Gaceta ecológica número especial, 84: 8-15.

Barala H., Guariguata M. R. and Keenan R. J., 2016. A proposed framework for assessing ecosystem goods and services from planted forests. Ecosystem Services, 22: 260-268.

Barnaud C., Antona M. and Marzin J., 2011. Vers une mise en débat des incertitudes associées à la notion de service écosystémique. VertigO, 11(1).

Boyd J. and Banzhaf S., 2007. What are ecosystem services? The need for standardized environmental accounting units. Ecological Economics, 63: 616-626.

Brouwer R., Brander L., Kuik O., Papyrakis E. and Bateman I., 2013. A synthesis of approaches to assess and value ecosystem services in the $E U$ in the context of TEEB. Institute for Environmental Studies, Amsterdam: VU University.

Burkhard B., Kroll F., Nedkov, S. and Müller, F., 2012. Mapping ecosystem service supply, demand and budgets. Ecological Indicators, 21: 17-29.

Camacho V. and Ruiz A., 2011. Marco conceptual y clasificación de los servicios ecosistémicos. Revista Biociencias, 1(4): 3-15.

Carbonero M.D., Fajardo E., Leal J.R.L., Guerrero J.E., García A. and Fernández P., 2013. Modelos de integración del ganado ovino en el olivar andaluz. Pastos, 43(1): 35-45.

Costanza R., d'Arge R., de Groot R., Farber S., Grasso M., Hannon B., Limburg K., Naeem S., O’Neil R.V., Paruelo J., Raskin R.G., Sutton P. and van den Belt M., 1998. The value of ecosystem services: putting the issues in perspective. Ecological Economics, 25(1): 67-72.

Crossman N.D., Burkhard B., Nedkov S., Willemen L., Petz K., Palomo I., Drakou E.G., Martín-López B., McPhearson T., Boyanova K., Alkemade R., Egoh B., Dunbar M.B. and Maes J., 2013. A blueprint for mapping and modelling ecosystem services. Ecosystem Services, 4: 4-14.

Daily G.C., 1997. Nature's Services: Societal Dependence on Natural Ecosystems. Washington, DC: Island Press.
Daily G.C., Polasky S., Goldstein J., Kareiva P.M., Mooney H.A., Pejchar L., Ricketts T.H., Salzman J. and Shallenberger R., 2009. Ecosystem services in decision making: time to deliver. Frontiers in Ecology and the Environment, 7: 21-28.

Daly H.E., 1977. Steady-state economics. In: Cahn M.A. and O'Brien R. (eds.). Thinking about the Environment: Readings on Politics, Property, and the Physical World. New York: M.E. Sharpe, Inc., 250-255.

Darnhofer I., 2014. Resilience and why it matters for farm management. European Review of Agricultural Economics, 41(3): 461-484.

De Chazal J., Quétier F., Lavorel S. and Van Doorn A., 2008. Including multiple differing stakeholder values into vulnerability assessments of socio-ecological systems. Global Environmental Change, 18: 508-520.

Delibes-Mateos M., Farfán M.A., Olivero J. and Vargas J.M., 2013. Impact of land-use changes on red-legged partridge conservation in the Iberian Peninsula. Environmental Conservation, 39(4): 337-346.

Ehrlich P.R. and Ehrlich A.H., 1981. Extinction: The Causes and Consequences of the Disappearance of Species. New York: Random House.

Ehrlich P.R. and Mooney H.A., 1983. Extinction, substitution, and ecosystem services. BioScience, 33: 248-254.

EME, Evaluación de los Ecosistemas del Milenio en España, 2011. Evaluación de los Ecosistemas del Milenio en España. Sintesis de resultados. Madrid: Fundación Biodiversidad. Ministerio de Medio Ambiente y Medio Rural y Marino.

Engel S., Pagiola S., Wunder S., 2008. Designing payments for environmental services in theory and practice: an overview of the issues. Ecological Economics, 65: 663-675.

European Commission, 2010. The CAP Towards 2020: Meeting the food, natural resources and territorial challenges of the future. $\operatorname{COM}(2010) 672$ final. European Commission, Brussels.

FAO, 2007. El estado mundial de la agricultura y la alimentación. Pagos a los agricultores por servicios ambientales. Colección FAO: Agricultura N. 38, Roma.

Gallardo-Cobos R. and Ceña-Delgado F., 2009. La multifuncionalidad de la agricultura y la Política Agraria Común. In: Sayadi S. and Parra C. (eds.), Multifuncionalidad agraria, desarrollo rural y políticas públicas: Nuevos desafios para la agricultura. Junta de Andalucía, Instituto de Investigación y Formación Agraria y Pesquera Consejería de Agricultura y Pesca, Sevilla, 63-78. 
Garbach K., Milder J.C., De Clerck F.A.J., Driscoll L., Montenegro M. and Herren B., 2016. Examining multi-functionality for crop yield and ecosystem services in five systems of agroecological intensification. International Journal of Agriculture Sustainability, 1-22.

Gómez J.A., 2010. Sostenibilidad de la producción de olivar en Andalucía. Consejería de Agricultura y Pesca, Junta de Andalucía, Sevilla.

Gordon L.J., Finlayson C.M. and Falkenmark M., 2010. Managing water in agriculture for food production and other ecosystem services. Agricultural Water Management, 97(4): 512-519.

Guzmán J.R. and Navarro R.M., 2005. Restauración ecológica de olivares marginales: potencialidades y limitaciones. Ecosistemas, 14(2): 116-131.

Hein L., van Koppen K., de Groot R.S. and van Ierland E.C., 2006. Spatial scales, stakeholders and the valuation of ecosystem services. Ecological Economics, 57(2): 209-228.

Kallas Z., Gómez-Limón J.A., Arriaza M. and Nekhay O., 2006. Análisis de la demanda de bienes y servicios no comerciales procedentes de la actividad agraria: el caso del olivar de montaña andaluz. Economía Agraria y Recursos Naturales, 6(11): 49-79.

Knight A., Cowling R.M., Rouget M., Balmford A., Lombard A.T. and Campbell B.M., 2008. Knowing but not doing: selecting priority conservation areas and the research-implementation gap. Conservation Biology, 22: 610-617.

López J.E., 2012. Estimación de la función sumidero de las nuevas plantaciones de olivar en Andalucia: 1990-2011. Departamento de Prospectiva de la Agencia de Gestión Agraria y Pesquera de Andalucía (AGAPA), Consejería de Agricultura, Pesca y Medio Ambiente, Junta de Andalucía, Sevilla.

López L., Fernández M.P. and López-Bellido P.J., 2014. Balance y huella del carbono del olivar. Vida rural, 375: 3-14.

MA, Millennium Ecosystem Assessment, 2003. Ecosystems and Human Well-being: A Framework for Assessment. Washington, D.C.: Island Press.

MA, Millennium Ecosystem Assessment, 2005. Ecosystems and Human Well-being: A Framework for Assessment: Synthesis., Washington, D.C.: Island Press.

MacDonald D.H., Bark R.H., Coggan A., 2014. Is ecosystem service research used by decision-makers? A case study of the Murray-Darling Basin, Australia. Journal of Landscape Ecology, 29: 1447-1460.

Maes J., Egoh B., Willemen L., Liquete C., Vihervaara P., Schägner J.P. and Bouraoui F., 2012. Mapping ecosystem services for policy support and decision making in the European Union. Ecosystem Services, 1(1): 31-39.

Mendoza G.A. and Martins H., 2006. Multi-criteria decision analysis in natural resource Management: A critical review of methods and new modeling paradigms. Forest Ecology and Management, 230(1-3): $1-22$.

Montes C. and García M., 2012. La evaluación de los Ecosistemas del Milenio enAndalucía. Consejería de Agricultura, Pesca y Medio Ambiente, Junta de Andalucía, Sevilla.

Moreno G., Franca A., Pinto-Correia M.T. and Godinho S., 2014. Multifunctionality and dynamics of silvopastoral systems. In: Baumont R., Carrère P., Jouven M., Lombardi G., López-Francos A., Martin B., Peeters A. and Porqueddu C. (eds.), Options méditerranéennes Series A, Mediterranean Seminars N. 109, 421-436.

Mulazzani L., Manrique R. and Malorgio G., 2017. The Role of Strategic Behaviour in Ecosystem Service Modelling: Integrating Bayesian Networks with Game Theory. Ecological Economics, in press.

Muradian R., Corbera E., Pascual U., Kosoy N. and May P.H., 2010. Reconciling Theory and Practice: An Alternative Conceptual Framework for Understanding Payments for Environmental Services. Ecological Economics, 69(6): 1202-1208.

Nelson E., Mendoza G., Regetz J., Polasky S., Tallis H., Cameron D.R., Chan K.M.A., Daily G.C., Goldstein J., Kareiva P.M., Lonsdorf E., Naidoo R., Ricketts T.H. and Shaw M., 2009. Modeling multiple ecosystem services, biodiversity conservation, commodity production, and trade-offs at landscape scales. Frontiers in Ecology and Environment, 7: 4-11.

Pandeya B., Buytaert W., Zulkafli Z., Karpouzoglou T., Mao F. and Hannah D.M., 2016. A comparative analysis of ecosystem services valuation approaches for application at the local scale and in data scarce regions. Ecosystem Services, 22: 250-259.

Pascual U., Muradian R., Brander L., Gómez-Baggethun E., Martín-López B., Verma M., Armsworth P., Christie M., Cornelissen H., Eppink F., Farley J., Loomis J., Pearson L., Perrings C. and Polasky S., 2010. The Economics of Valuing Ecosystem Services and Biodiversity, TEEB document, chapter 5.

Paudyal K., Baral H., Burkhard B., Bhandari S.P. and Keenan R.J., 2015. Participatory assessment and mapping of ecosystem services in a data-poor region: case study of community-managed forests in central Nepal. Ecosystems Services, 13: 81-92.

Pérez y Pérez L., Egea P. and Sánz-Cañada J., 2013. Valoración de externalidades territoriales en denominaciones de origen de aceite de oliva mediante técni- 
cas de Proceso Analítico de Red. Información Técnica Económica Agraria (ITEA), 109(2): 239-262.

Raudsepp-Hearne C., Peterson G.D. and Bennett E.M., 2010. Ecosystem service bundles for analyzing trade-offs in diverse landscapes. Proceedings of the National Academy Sciences USA, 107: 52425247.

Rivas-Martínez S., 2004. Worldwide Bioclimatic Classification System. The Phytosociological Research Center, Madrid, España.

Rocamora B., Colombo S., Sayadi S. and Estévez C., 2013. Los impactos marginales del olivar ecológico de montaña andaluz frente al convencional post-condicionalidad: una visión de los expertos. Revista Española de Estudios Agrosociales y Pesqueros, 234: 49-82.

Rocamora-Montiel B., Glenk K. and Colombo S., 2014. Territorial management contracts as tool to enhance the sustainability of sloping and mountainous olive orchards: Evidence from a case study in Southern Spain. Land Use Policy, 41, 313-324.

Saaty R.W., 2003. Decision making in complex environments. The Analytic Hierarchy Process (AHP) for decision making and the Analytic Network Process (ANP) for decision making with dependence and feedback. Super Decisions, Creative Decisions Foundation, Pittsburgh, EE.UU.

Saaty T.L. and Takizawa M., 1986. Dependence and independence from linear hierarchy to nonlinear network. European Journal of Operational Research, 26: 228-237.

Saaty T.L., 2001. The analytic network process: decision making with dependence and feedback. Pittsburgh: RWS Publications.

Saaty T.L., 2005. Theory and Applications of the Analytic Network Process. Pittsburgh: RWS Publications.

Sánchez J., 2003. Evaluación de la sustentabilidad de sistemas de manejo de olivares ecológicos y convencionales en Los Pedroches. Asociación Comité Andaluz de Agricultura Ecológica (C.A.A.E.), Sevilla.

Sanz J., Hervás I., Sánchez F. and Coq D., 2011. Investigación e innovación en el sector del aceite de oliva en España. Problemas, oportunidades y prioridades de $I+D+i$. Instituto de Economía, Geografía y Demografía. Centro de Ciencias Humanas y Sociales, Madrid.

Sanz-Cañada J., García-Brenes M.D. and Barneo-Alcántara M., 2015. Value Chain and Typicity Analysis in Jaén Mountain Olive Oil, Spain. New Medit, 14(3): 50-60.
Sánchez-Zamora P., Gallardo-Cobos R. and Ceña-Delgado F., 2017. Análisis de los factores de resiliencia en territorios rurales de Andalucía mediante técnicas de Proceso Analítico en Red (ANP). Información Técnica Económica Agraria (ITEA), 113(1): 68-89.

Sayadi S., González-Roa M.C. and Calatrava-Requena J., 2005. Ranking versus scale rating in conjoint analysis: Evaluating landscapes in mountainous regions in southeastern Spain. Ecological Economics, 55: 539-550.

Sayadi S., González-Roa M.C. and Calatrava-Requena J., 2009. Public preferences for landscape features: the case of agricultural landscape in mountainous Mediterranean areas. Land Use Policy, 26(2): 334-344.

SIMA, Sistema de Información Multiterritorial de Andalucía, 2016. Instituto de Estadística y Cartografía de Andalucía. Junta de Andalucía, Sevilla.

Sipahi S. and Timor M., 2010. The Analytic Hierarchy Process and Analytic Network Process: An overview of applications. Management Decision, 48: 775-808.

Swinton S.M., Lupi F., Robertson G.P. and Hamilton S.K., 2007. Ecosystem services and agriculture: cultivating agricultural ecosystems for diverse benefits. Ecological Economics, 64(2): 245-252.

TEEB, 2010. The Economics of Ecosystems and Biodiversity Ecological and Economic Foundations. Edited by Pushpam Kumar. London and Washington: Earthscan.

The World Commission on Environment and Development, 1987. Our Common Future. New York: Oxford University Press, 43.

UK National Ecosystem Assessment, 2014. The UK National Ecosystem Assessment: Synthesis of the Key Findings. UNEP-WCMC, LWEC, UK.

Villanueva A.J., Gómez-Limón J.A. and Arriaza M., 2014. Influencia de los factores de gestión en la producción de bienes públicos en el olivar de regadío. Revista Española de Estudios Agrosociales y Pesqueros, 237: 77-116.

Wam H.K., Bunnefeld N., Clarke N. and Hofstad O., 2016. Conflicting interests of ecosystem services: Multi-criteria modelling and indirect evaluation of trade-offs between monetary and non-monetary measures. Ecosystem Services, 22: 280-288.

Westman W.E., 1977. How much are nature's services worth? Science, 197(4307): 960-964.

Wunder S., 2005. Payments for Environmental Services: Some Nuts and Bolts. Occasional Paper N. 42, CIFOR, Bogor. 